\title{
形状処理のコンポーネント化による パラメトリックデータの共有化*
}

\author{
松木則夫** 徳永仁史 ${ }^{* *}$ 小島俊雄** 木村文彦***
}

\begin{abstract}
A Component Representation of History-Based Parametric Modeling Data
\end{abstract}
\author{
Norio MATSUKI, Hitoshi TOKUNAGA, Toshio KOJIMA and Fumihiko KIMURA
}

This paper describes a method for sharing history-based parametric modeling data of free-form shape with different $\mathrm{CAD}$ systems and storing them in a form of text information. Parametric is quite effective, however, parametric modeling data is valid only in the exact same CAD systems because these data depends deeply on the programming algorithms and system tuning parameters such as tolerance. In the method, guidelines to decompose a conventional CAD operation into appropriate programming units (software components), which can be sharable among different CAD systems, are shown. B-spline surface generation system is developed to verify the effectiveness.

Key words : software component, parametric modeling data, data exchange, object exchange, data management, mark-up language, tolerance

\section{1. 緒言}

多くの CAD システムではユーザ固有の形状処理機能を実現 するため履歴再生パラメトリックモデリング(history-based parametric modeling)やそれと連携したフィーチャ処理を用い ている.しかしながら操作履歴(operation history)の再害行に よるモデリング手法りには,データの永続性が無いという問題が ある. 操作履歴とは， $\mathrm{CAD}$ 利用者が入力したデータや，そのデ 一タを入力とする「フィレット面作成」のような形状処理等の プログラム(以下，オペレーション)の名前, およびそのオペレ ーションの処理結果を次のオペレーションに引き渡す記録のこ とで，その情報によって同一のモデリングが再現できる，本報 では，操作履歴を含めた履歴再生パラメトリック処理に必要な データを一括して，パラメトリックデータと呼ぶことにする. また，データの永続性とは，本報では，個々のシステムやその 設定值から独立にデータが利用できるという意味で使用する. たとえば国際標準 ISO 10303 (STEP)形式の図形データは永続 性があると考えられる.

これまでパラメトリック処理に関する研究は, 寸法值の変更 によって, 作成された形状の位相構造が変わることによって起 こる問題に対処する研究がほとんどである2 文. しかし, 位相構 造が変化しない場合でもパラメトリックデータにデータの永続 性が無いという問題が存在する，本報では，位相が変化しない 場合の履歴再生パラメトリック処理を対象として議論する.

パラメトリックデータによる形状作成の手法は，オペレーシ ヨンが，同じ入力に対して「常に」同じ結果を出力すること， すなわち「オペレーションによる再現性」が前提になっている. しかし，個々の CAD システムではアリゴリズムや誤差の取り 扱いなどが異なり，「オペレーションによる再現性」の前提は必 ずしも正しいとは言えない，また，同じ CAD システムにおい ても, バージョンアップを何回か繰り返すと, 以前のパラメト

\footnotetext{
* 原稿受付 平成 14 年 8 月 22 日

**正会員産業技術総合研究所(つくば市並木 1-2)

*** 正 会 員 東京大学大学院(文京区本郷 7-3-1)
}

リックデータが動作しなくなることがある，その主な原因は， 誤差に代表されるプログラム内のパラメータ值の変更にある. バージョンアップは, 単純なバグの修正だけでなく, 形状が作 成できないといった，特定のデータで発生した不具合に対処す

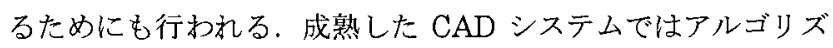
ムの見直しの余地は少なく, 特定のデータで発生した不具合一 の対処として誤差などのパラメータの修正が一般的に行われる. しかし，この修正の副作用として修正前に正常であったデータ の中に, 不具合が生じることが起こる.このように, プログラ ムに過度に依存したパラメトリックデータは保存対象のデータ としては不適切であり，データの永続性が無いと考えられる.

パラメトリックデータの永続性に対する提案や研究発表は少 ない. それは, 市販 CAD システムの処理方法等が公開される ことが無いため, $\mathrm{CAD}$ 開発ベンダー以外がこの問題の解決策を 提案することが困難であることに由来する. CAD 開発ベンダー の対応は, バージョンアップ毎にパラメトリックデータの作り 直しを推奨したり，結果の形状データを残すことを推奖したり といったものが主で, パラメトリックデータを永続的にするた めの提案はほとんど見られない.

パラメトリックデータの永続性を保つためには, オペレーシ ヨンを交換する手法が必要である.一般に, CAD 閒で交換され るデータとは, 幾何データと幾何データに付随した属性データ である.しかし，パラメトリックデータはこれらのデータだけ でなく,オペレーションの意味に強く依存している.このため, オペレーションのプログラムあるいはそのアルゴリズムを何ら かの方法で交換する手段が必要である．さらにこのオペレー ションの交換において誤差の取り扱いが明示的に行われる仕組 みが必要となる.

そこで, 図 1 のような手順でパラメトリックデータおよびオ ペレーションを交換することが有効と考えた.

（1）オペレーションを，いくつかの, 処理単位に分解する.こ の単位をコンポーネントと呼ぶ (コンポーネントの実体はオ ブジェクト指向でいうオブジェクトである),

（2）分解されたコンポーネントに名称を付ける,

（3）コンポーネントの名称とその引数の対応関係, および入力 


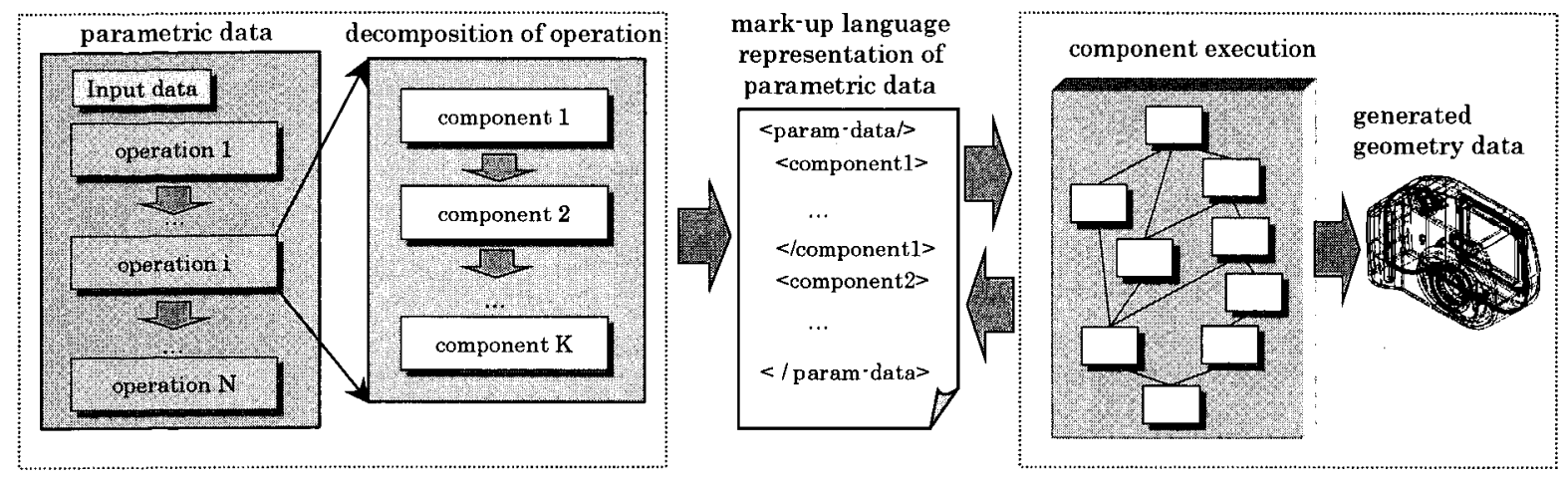

Fig.1 Basic concept of proposed parametric data structure

データをタグ言語により記述する，

(4) (3)の結果と(1)のオペレーションを対応させる機構を作り, 相互に交換可能とする.

本報は,この手順の(1)にまず着目し, どのようなコンポーネ ントに分割すべきであるかという基準を示し，その有効性を示 すことが目的である.また，この手法は従来の $\mathrm{CAD}$ データ交 換から, CAD オブジェクト交換への移行の提案にもなっている.

\section{2. 研究の背景と関連研究}

\section{1 許容誤差によって起こる問題}

オペレーションが，同じ入力に対して「常に」同じ結果を出 力することがなぜ困難か, という理由は, CAD の形状モデリン グにおいて，座標值などの浮動小数点による「実数演算の結果 に基づいて立体と立体が接触している」のような論理的な判断 を行う必要があるためである. 計算機の丸め誤差で発生する差 異を同一と見な寸限界の值を「数値計算の誤差 (error of floating point arithmetic)」と呼ぶことにする.たとえば，あ る論理判断を行うプログラムにおいて，その論理判断の境界付 近で数值計算の結果に誤差が生じるような入力データの場合に は, 同一アルゴリズムで設計しても，異なった判定をすること が起こる.

さらに大きな問題が「許容誤差(tolerance)」と呼ばれる, 数 值計算の誤差よりもさらに大きな值を持つパラメータの存在で ある5.これは，二つの異なった点を同一と判定するときや，二 つの角度を同一と判定するときなどに利用するもので，たとえ ば自動車の設計製造では, 二つの点の同一判定に, $0.001 \mathrm{~mm}$ と か $0.01 \mathrm{~mm}$ といった許容誤差が利用されることが多い.これは， 数値計算の誤差と比較すると非常に大きな值である.

この許容誤差は, 曲面と曲面の交線計算処理など, ある幾何 要素で表現される点集合を, 異なった幾何要素で近似するとき の収束の判定に利用される6). 数值計算の誤差より逻かに大きな 值である許容誤差が必要となる理由は, 交線計算等の処理で作 成された曲線は, 次の曲面作成に利用され, さらに次の処理に 利用されると言った具合に, 幾何処理の結果が何度も利用され るため, これらの近似計算に数值計算の誤差を利用すると曲線 の制御点やノット数が膨大になり，ほとんど実用に耐えないほ ど品質が劣化するためである.

このため, どの市販 CAD システムでも, 経験的に求められ た，ノットや構成点が再利用に耐えうるような許容誤差が使用 されている.

この許容誤差の存在により，たとえば，2つの空間曲線が許 容誤差の直径を持つ同一の球を通過しているとき, その球内の

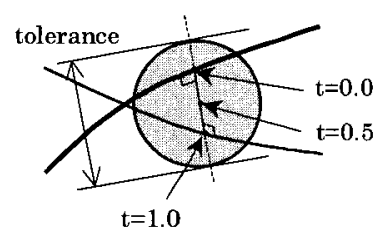

(1) Tolerance allows ambig uous intersection point of two spatial free-form curves

Fig.2 Tolerance affects $\mathrm{CAD}$ algorithm
どの点を交点としてもよいことになる(図2(1)).このように, 許 容誤差值を直径とする球の内部のどの点を，「交点」とするのか， ということを, 本報では「許容誤差に起因する任意性」と呼ぶ. 著者等は, この許容誤差の存在と, 許容誝差に起因する任意性 がパラメトリックデータの永続性を損なう大きな要因と考える.

もし，すべての市販 CAD システムが，図2(1)について「共通 垂線を $\mathrm{t}=0.0$ から $\mathrm{t}=1.0$ にパラメータ表現したときの中点 $\mathrm{t}=0.5$ を交点とする」という具合に, 許容誤差に起因する任意性を無 くすことができれば，同じ許容誤差值を利用することでパラメ トリックデータの永続性は保たれる.

しかし，実際には，業務データでプログラムが適正に動作す るようにするための, システム調整7) (system tuning)の手段 として, 許容誤差とその任意性が利用されている. その理由の 一つは, 許容誤差が存在すると, 点の同一性についての推移律 が成立しなくなることが原因である(図2(2)). 許容誤差の值が大 きくなると,この推移律を満たさない点データの量が増大する. このため，単純なアルゴリズムでは処理が破綻することが多く なる．誤差程度に距離が離れたある点が同一点として含まれて いるということを前提にオペレーションのアルゴリズムを設計 するのは，かなりの経験と技巧を必要とし，その結果として， 誤差值とその任意性を調整することが行われる.

許容誤差の存在を許す限り，処理の破綻を本質的に解決する ことはほとんど不可能である.しかし，現在の $\mathrm{CAD}$ が有効な ツールであるということは, ある範囲内で許容誤差の值と許容 誤差に起因する任意性の調整が整合的に行われていることを意 味する。

現状のパラメトリックデータを見ると, 許容誤差の值を変更 できるものはあるが，その任意性の取り扱いを知ることはでき ない、これらは，許容誤差に起因する任意性の調整方法が一つ のオペレーションの内部に隠蔽されているためである。もし, 許容誤差の值と許容誤差に起因する任意性の調整が可能となる 
単位にプログラムが作られ，パラメトリックデータとして保存 されていれば，永続性の問題を大幅に軽減することが可能では ないか, といらのが本研究の着想である.

\section{2 関連研究}

パラメトリック処理に関する研究は，主に寸法值の変更によ り，結果の図形の位相が寸法変更前と変わってしまい，それ以 降の処理の入力となる位相要素との対応関媇が維持できない問 題，いわゆる，永続的名前付け (persistent naming) 問題を取 り扱うもの2) 4)であり本研究とは目的が異なる.これらの研究 が対象とする図形も，平面や解析図形といった，許容誤差の取 り扱いが問題とならない図形が主である。また，パラメトリッ クデータ交換を目的としたパラメトリックデータ構造に関する 研究8)もるが, 平面や解析図形といった図形が対象で, 許容詥 差に関する議論は無く, 本研究の対象とは異なっている. また, パラメトリックを含めた問題を指摘し，すべてのアルゴリズム のライブラリによる共有化の提案》もあるが,これはパラメトリ ックデータの交換という考え方とは異なる.

STEP の ISO/TC184/SC49において, パラメトリックデータ の標準化が検討されているが，市販 CAD のパラメトリックデ ータ形式に基づいたフォーマットの共通化の議諭であり，オペ レーションの再現性やデータの永続性についての議論は行われ ていない.

一方, 数值計算の誤差に起因する問題に対して, 頑健な処理 を行う研究も多くある10)が，本報の研究は，誤差の研究ではな く，既存の CAD アルゴリズムを細分するときの基準として許 容誤差に着目したもので，この点が従来の頑健な処理に関する 研究とは異なっている.

コンポーネント化については，ソフトウェア工学分野で盛ん に研究が行われている11)が，コンポーネントをどのような単位 で作成するかの方法論については，そのソフトウェアが対象と する分野固有の問題とされ，沉用な基準が示されることは無い. 市販 CAD の開発においてもコンポーネント化が行われている が，その基準が公開されないため議論が困難である。

\section{3. 形状処理のコンポーネント化}

\section{1 形状作成手法独立な図形}

パラメトリックデータの中には問題が起こりにくい種類のも のがある、それは，平面，線分， 円弧などの解析的な図形を取 り扱うものである。一方，自由曲面や自由曲面上のフィレット を含むものは問題が起こりやすい，これは，取り扱う図形の作 成方法に関係すると思われる，平面や円弧などは，原点や方向 ベクトル，半径といった，限られたパラメータによって，2つ の異なったシステム間で数值計算の誤差を除いて点集合として 同じ形状を得ることができる、これを，「形状作成手法独立な図 形」と呼ぶことにする.

一般的に，ある要求仕様があったとき，その要求仕様を実現 するコンポーネントには，その実装方法によらず，同じ結果が 得られるものがある.たとえば空間の 3 点から平面を定義する 場合, 連立 1 次方程式を解く方法や， 3 点から 2 つ独立な心゙ クトルを求めて外積を計算する方法など様々な実装方法がある が，その結果は同じである.

図形を作成する処理に限らず，同一の入力データに対して数 值計算の誤差を除いて同じ結果を得られる処理の単位を本報で は「手法独立な形状処理コンポーネント」あるいは简単に「独

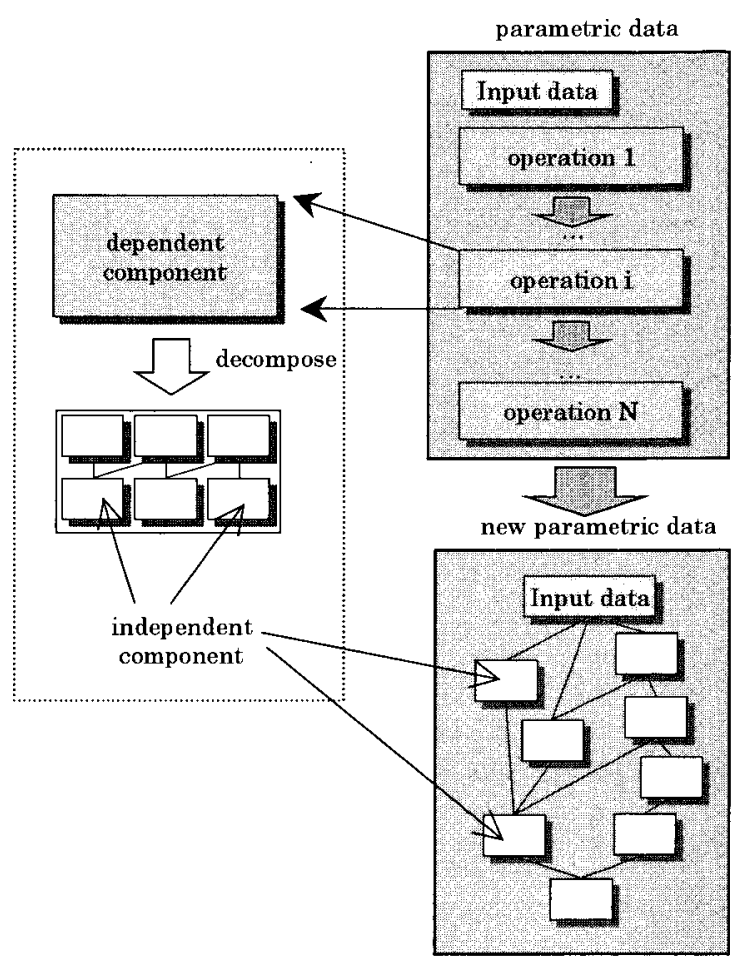

Fig.3 Decomposition process of dependent component to independent components

立コンポーネント(independent component)」と呼ぶことにす る.これは，同一人力に対する出力結果が要求仕様によって(数 值計算の誤差を除いて)確定し，実装方法に対して独立なプログ ラムであることを意味している．さらに，独立コンポーネント と，その要求仕様は次の条件を満足するものとする.

(1) 要求仕様において, コンポーネント内で使用されるパラメ 一タのうち, その值の変更が出力の図形に数値計算の誤差以 上の違いを生じるものが特定されている。

（2）コンポーネントの害装において，(1)で特定されたパラメー タについて, コンポーネントの引数などとして, 外部からの 変更が可能となっている.

例えば，入力曲線上に $\mathrm{N}$ 個の点を作成する場合，曲線のパラ メータを $(\mathrm{N}-1)$ 等分するのは任意性が無いが, 曲線長の $(\mathrm{N}-1)$ 等分は曲線長計算のアルゴリズムに依存する，従って，曲線長 を計算するコンポーネントを独立コンポーネントにする場合， 積分の微小区間長などのパラメータは引数にする必要がある.

なお，本報におけるコンポーネントの独立性は，数学におけ る線形空間の基底の独立性とは意味が違う。(独立コンポーネ ント作成可能な）要求仕様が与えられたとき，幾つかの基底と なる独立コンポーネントが自然に定まることはない，与えられ た要求仕様をそのまま実装すれば一つの独立コンポーネントと なり，複数の要求仕様に分割すれば，その数の独立コンポーネ ントが対応する.

一方, 自由曲面やフィレット面などは，必ずしも同一の入力 データに対して(数值計算の䛊差を除いて)同じ結果が得られる とは言えない，自由曲面作成やフィレット面作成についての計 算幾何学的な手法は確立されているが, これらのプログラミン グの実装方法は様ヶであり，CAD システムごとに異なった形状 データを作成している. 実装方法が異なる主な要因は，前節で 述べた, 許容誤差の值と許容誤差に起因する任意性である。こ の上うな図形を，「形状作成手法依存な図形」と呼ぶ. 


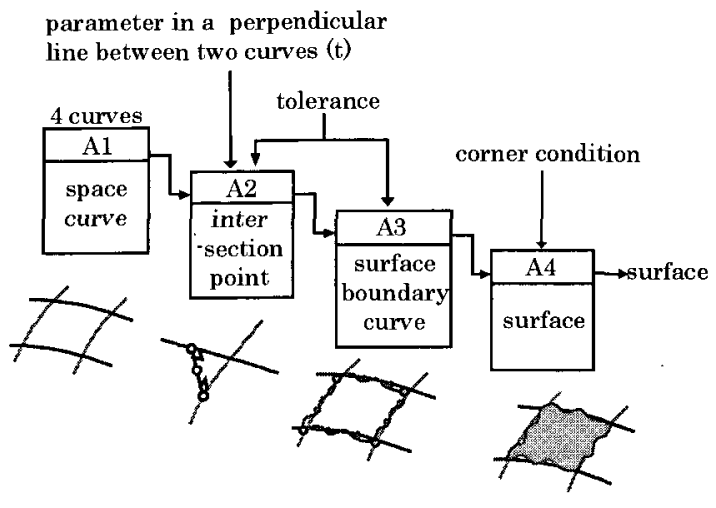

Fig.4 Surface generation process composed of independent components

そして，手法独立な形状処理コンポーネントと同様に，形状 作成手法依存な図形を作成する処理の単位を「手法依存な形状 処理コンポーネント」あるいは「依存コンポーネント (dependent component)」と呼ぶことにする. 依存コンポーネ ントは，要求仕様は同じであるが，実装方法の違いによって， 同一の入力に対して, 出力結果が数值計算の誤差より遥かに大 きな違いが生じることがあるプログラム，才なわち，実装方法 に依存するプログラムである.

そこで,

(1) $\mathrm{CAD}$ の 1 つのオペレーションは1つ以上の依存コンポー ネントか，1つ以上の独立コンポーネントとして表現できる，

（2）依存コンポーネントは1つ以上の独立コンポーネントの組 み合わせに分割，あるいは，変換できる，

（3）独立コンポーネントは，1つ以上の独立コンポーネントの 組み合わせに分割できる，

に着目する（1)は明らかである，依存コンポーネントにある数 值計算の誤差以上の違いを生じる原因となるパラメータを，コ ンポーネントの引数となるように変更することは，一般のプロ グラム言語で実現可能である：この変更に対応する新たな要求 仕様は独立コンポーネントの定義を満足する.一般に，ある程 度の規模の要求仕様を複数の要求仕様に分割することは可能で ある，そこで，依存コンポーネントが巨大で，引数の数がシス テムの制限を超えるときは，依存コンポーネントの要求仕様を 分割する. 分割されたコンポーネントに依存コンポーネントが 含まれているならば，システムの制限を超えなくなるまでこの 処理を繰り返す。この分割時に引数を各コンポーネントに適切 に割り当てるようにすれば，分割された要求仕様に対応するコ ンポーネントは独立となる。このようにして(2)と(3)が成立する.

\section{2 独立コンポーネントによるパラメトリックデータ表現}

この結果, パラメトリックデータは CAD のオペレーション の組み合わせであるから，パラメトリックデータを独立コンポ 一ネントの組み合わせで表現可能となる，その過程の概略を図 3に示す.

独立コンポーネントは，入力データが同一であれば，数值計 算の誤差を除いて同一の結果を出力寸る。これは，許容誤差お よび許容誤差の任意性を取り扱うパラメータが，独立コンポー ネントの引数であるためで, 前節で述べた誤差の取り扱いに関 する問題は, 独立コンポーネント間の関係として記述されるこ とになる。

このように，既存のパラメトリックデータを独立コンポーネ ントに分割する手法により，従来のパラメトリックデータの永

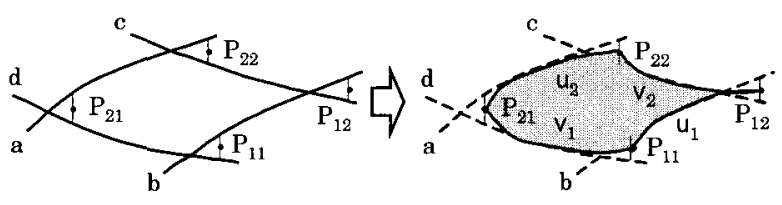

(1) Surface generation with 4 spatial free-form curves which have "intersection points" within a tolerance

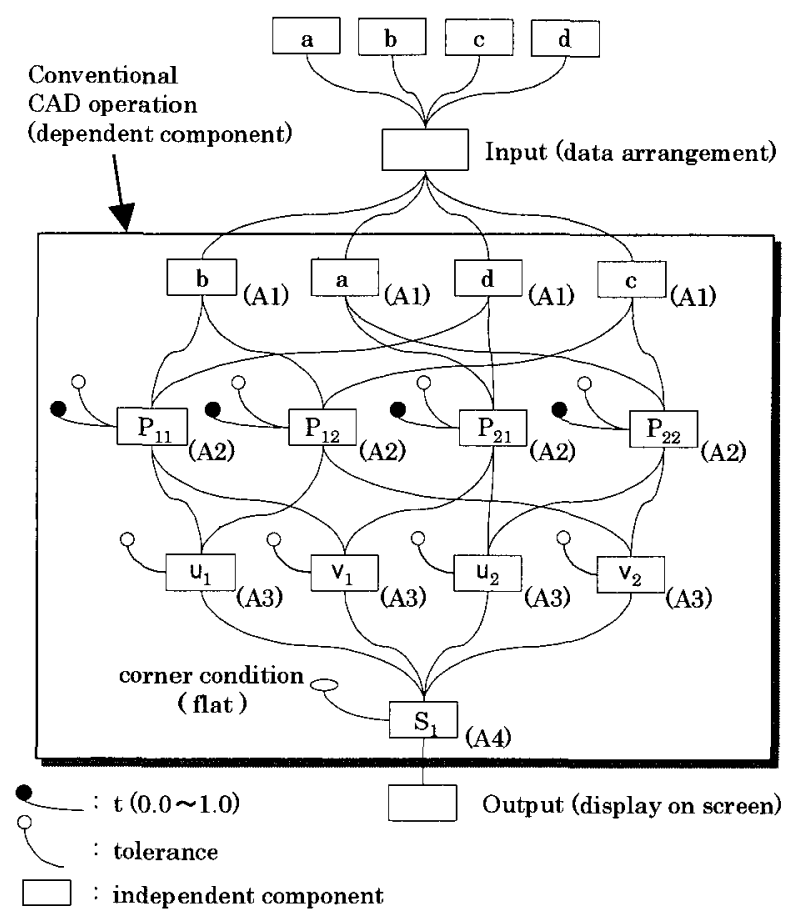

(2) A diagram of independent components which represent a surface generation operation

Fig.5 An independent component representation of a surface generation operation

続性を損なう要因をオペレーションから分離することが可能と なった. 分離された許容誤差についての情報は, 入力データと ともにタグ語語を利用して記録，保存することにより永続性が 得られる.

\section{3 必要とされる CAD システムの構造}

このパラメトリックデータを利用するためには, CAD システ ムが次のような構造をもつ必要がある.

（1）他のシステムで定義された独立コンポーネントの名前に 対応した処理(コンポーネント)がある,

(2) オペレーションがコンポーネントを組み合わせて奏行で きる,

（3）タグ言語表現にもとづいてコンポーネントを組み合わせ てオペレーションを構成できる， である。

著者等は, 平成 13 年度から「設計・製造支援アプリケーシ ヨンのためのプラットフォームの研究開発」12)に着手し、 コン ポーネントを連携させる基盤としてのプラットフォーム機能を 研究開発中でこれは(1)から(3)を実現している.

\section{4. 応用と結果}

自由曲面の $\mathrm{CAD}$ オペレーションについて，上記プラットフ 


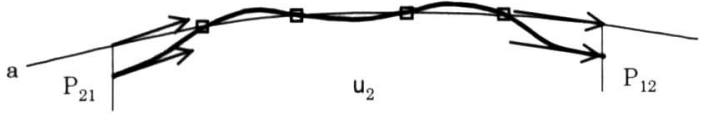

Fig.6 Uniform B-spline curve " $u_{2}$ " is defined as an approximation of the curve " $a$ ", using points $\mathrm{P}_{21}, \mathrm{P}_{12}$ and parametrically equally spaced points on "a"

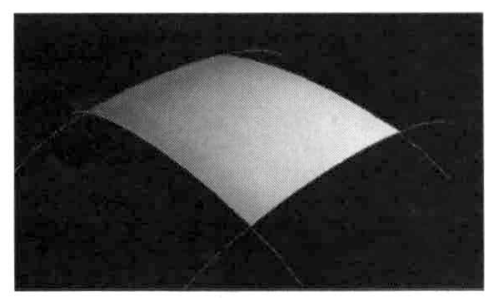

Fig.7 Surface with small tolerance value

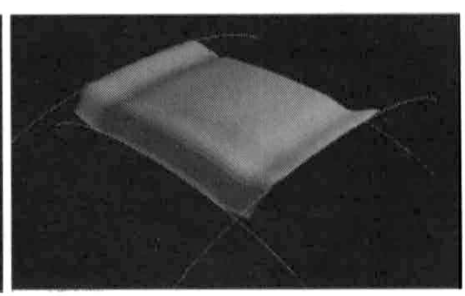

Fig. 8 Surface with large tolerance value
オーム上で依存コンポーネントを独立コンポーネントに分解し た実証例を示す.

\section{1 例 題}

4 つの空間曲線を与え，それらに囲まれた B-spline 曲面を作 成する処理を例題と寸る。この例は, 多くの $\mathrm{CAD}$ で依存コン ポーネントである. なぜなら, 入力として許容誤差值を与える ことは可能であるが, 許容誤差の取り扱いの任意性は個々の才 ペレーション内部に隠蔽されているためである.

本例は，図4に示寸ように(A1)から(A4)の 4 つのステップで 構成される. 各ステップで作成される形状の名称を図5 (1)に示 す．オブジェクト指向の考え方に基づき，各ステップで作成さ れる形状とコンポーネントは対応する．それら形状とコンポー ネントとの関倸を図5 (2)に示寸，大きな四角形で囲まれた範囲 が従来の依存コンポーネントであり, 小さい四角形が独立コン ポーネントを示す

簡単化のため，入力データの整列を行う入力コンポーネント と表示出力のコンポーネント, 数值計算の誤差については説明 を省略する.エラーなどの例外処理についても説明は省略する. また, 入力曲線データ等のオブジェクトもコンポーネントとし て説明する.

\section{2 独立コンポーネントの内容}

図4のステップ(A1)から(A4)をコンポーネント表現した図5(2) に従い，各ステップでの処理を説明する.

(A1) 空間曲線

空間曲線のコンポーネント表現で, 図5(2)の a, b , c，d がこ れに相当する. 形状データだけでなく, 曲線の生成メソッドや 問い合わせのメソッドを含む. 本例は 3 次 B-spline 曲線である. (A2) 交点

2 つの空間曲線の共通垂線上の点を交点として表現するコン ポーネントで, 図5(2)の $\mathrm{P}_{11}, \mathrm{P}_{12}, \mathrm{P}_{21}, \mathrm{P}_{22}$ がこれに相当する. この交点は，最終的に曲面の四隅の点となる，厳密に交叉して いない空間曲線の交点を求めるため, 許容誤差を利用して交点 相当を算出する（共通垂線の長さが許容誤差を越えた場合には 例外が発生し，これ以降の処理は行われないものとする）。の とき, 図2 (1)で示した交点の任意性があるため, 共通垂線をパ ラメータ表現したときの值 $\mathrm{t}$ を入力值としている.このように, 処理内容を明確にし, かつ任意性を持つパラメータを入力引数 とすることで，本コンポーネントは独立コンポーネントとする ことが可能となった. なお,このコンポーネントには, 入力と なる 2 つの空間曲線コンポーネントおよびその共通垂線の足の パラメータ值等の情報を持つ.

(A3) 曲面境界曲線

曲面の境界となる曲線を表現するコンポーネントで, 図5 (2) の $\mathrm{u}_{1} ， \mathrm{u}_{2} ， \mathrm{v}_{1}, \mathrm{v}_{2}$ がこれに相当する. (A1)の空間曲線を, 共通 垂線の足でトリムし，テンソル型曲面作成のために，向かい合 う曲線のノットベクトルが共通となるように曲線を構成する。
様々な手法があるが，ここでは，端点となる(A2)における接べ クトルを(A1)のものを利用するアルゴリズムを採用し，一様な ノット間隔となるように, ノットベクトルと通過点の再構成を 行う処理を採用した(図6)。なお，本報の実装はパラメー夕等間 隔としたが，線長等間隔とすることも可能である．作成された 曲線が，元の(A1)とどの程度類似しているかの判定は，(A1)曲 線から作成された曲線への垂線の足を求め, その長さを許容誤 差と比較することで判定した。この結果, 本コンポーネントも 独立コンポーネントとして構成することが可能となった。

(A4) 曲面

入力された曲面境界線と境界条件等から作成された面を表現 するコンポーネントで図5 (2)の $\mathrm{S}_{1}$ がこれに相当する. 双 3 次 B-spline 曲面であるため, 曲面の四隅の 2 階微分值が入力とし て必要であるが，本例では，簡単のためそれらが０ という条件 とした．また，向かい合う曲面境界曲線のノットベクトルの整 合は, 本コンポーネントから(A3)コンポーネントへの再分割要 請という形で実現した。

\section{3 考察}

(A1)から (A4) および入出力のコンポーネントをすべて JavaBeans で作成し，上記プラットフォーム上で実装した。

通常, (A1)から(A4)の処理は, 一つのオペレーションとして 表現される.このため, (A2)や(A4)の個々の許容誤差の值と(A2) の共通垂線上のパラメータ值 $\mathrm{t}$ のような許容誤差に起因する任 意性の值を外部から調整することはできない，ところが，本例 のように分解すると, これらのパラメータが調整可能となる. また, 同一仕様のコンポーネントを別途開発し, 旧来のコンポ 一ネントと入れ替えても, その出力結果は数值計算の誤差を除 いて同じにすることが可能である。これにより，依存コンポー ネントである曲面生成を, 独立なコンポーネントの組み合わせ で表現可能となった.

独立コンポーネントへの分解は, 本報以外にも様々な方法が 考えられる，たとえば，元の(A1)から(A4)までを含む従来と同 様規模のコンポーネントで多数の引数を持ったものを作成して 独立コンポーネントとすることは可能である. あるいは，本報 告より詳細な分割も可能である。これらに絶対的な基準は想定 し難く, ソフトウェアの開発や維持のコスト, コンポーネント の再利用性，流通性を考慮することが重要と思われる.

図7は通常の許容誤差を設定した曲面生成例である。図8は許 容誤差の值を大きくして強調した例である. 実際の $\mathrm{CAD}$ で作 成される曲面の多くは，図7のように見えるが，実際は図8のよ うな現象が起こっている，なお，図7と図8は，(A2)の t の值を すべて 0.5 とした場合である.

このように, 交点位置パラメータや様々なシステム調整のパ ラメータをコンポーネントの要求仕様の中で明確にし, 引数と して表現することで次のような利点がある.

（1） CAD オペレーションにおけるシステム調整は，ある特殊 


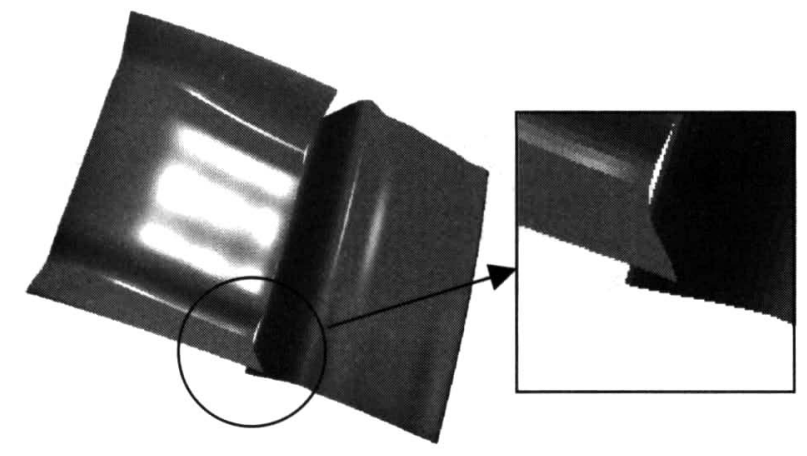

Fig.9 Surfaces become inconsistent at boundaries if they have different parameter tuning values of point position in perpendicular lines between curve pairs

なデータをエラー無く処理するために実施されることが多 い. 本手法で表現されたパラメトリックデータであれば, プ ログラムの修正ではなく, 独立コンポーネントの引数の值を 変更することで対応可能となる.

(2) $\mathrm{CAD}$ オペレーションの機能改善は, 独立コンポーネント 内部のアルゴリズムの改善か, 引数の值の変更か, 独立コン ポーネント群を新しい独立コンポーネント群に入れ替える か, のいずれかで表現可能と考えられる.これらの情報が利 用者に明らかであれば, 従来の独立コンポーネントが廃棄さ れずその動作が保証される限り, システムのバージョンアッ プ時における, 過去のパラメトリックデータの再処理は不要 となる.

（3）パラメトリックデータには複数の CAD オペレーション列 が関係する．異なる $\mathrm{CAD}$ オペレーションに対応寸る独立コ ンポーネント間の引数の対応関係が明らかな場合には, 引数 の值を調整することで, 安定なデータを作成することが可能 である.たとえば, 同一の空間曲線を共有する 2 つの曲面が あったとき, 独立にシステム調整されたオペレーションで曲 面が作成された場合には,この空間曲線の両端の交点位置に おいて, 前節(A2)で示したパラメータ $\mathrm{t}$ が, 例えば一方の曲 面では $\mathrm{t}=0.0$, 他方の曲面では $\mathrm{t}=1.0$ という值が設定される 可能性があり，そのとき図9のように違いが生じることにな る. 従来方法では, これに対処するための自由度をパラメト リックデータは持っていない. 本手法では, 同一の曲線を共 有する両端の(A2)コンポーネントがわかるため, それらの值 を同じに設定し，図10のように 2 曲面の境界線を一致させ ることができる.

許容誤差を利用して形状処理を行う限り，いかなるデータに 対しても安定な処理を作成することはほとんど不可能である. だからといって, 現状のパラメトリックデータのように, 依存 コンポーネントである CAD オペレーションの名前を保存する 手法では, 形状生成にとって重要なパラメータがオペレーショ ン内部に隐蔽され，その調整の自由度を利用者が活用できない ことは問題である。本手法では, これらの自由度を利用者が設 定することによって, パラメトリックデータの永続性を確保す ることが可能となる.

\section{4 課題と展望}

本手法を，実際の $\mathrm{CAD}$ システムに利用するためには幾つか の課題がある。一つは, 独立コンポーネントのより正確な定義 の確立と引数の標準化である. また, 運用のためには, 名前の 運営管理も重要である.また, タグ言語による記述の構造も課 題である. 今のところ, プログラミング言語相当の言語仕様が

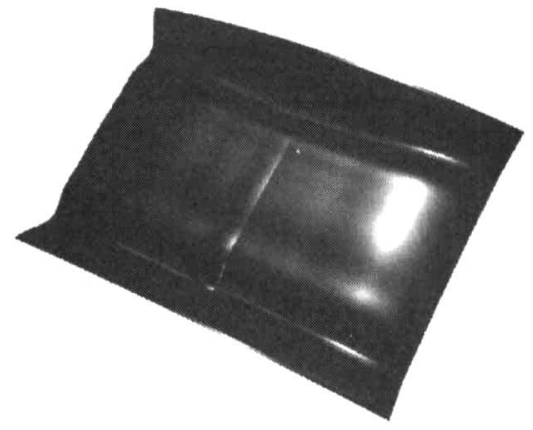

Fig.10 Surfaces become consistent at boundaries as the parameters set same at the common curve

求められることを想定し, 検討を行っている. 数值計算の誤差 に起因する問題も依然として残されている. また, 本報で提案 する手法は, $\mathrm{CAD}$ システムのアーキテクチャの変更を必要とし, 市販の $\mathrm{CAD}$ システムに対してすぐに導入することができるも のではない.

近年, パラメトリック機能を利用する企業が急増しており, 企業資産として永続的に利用寸るための方策は必要である。し かし, 現在の CAD のパラメトリック機能では, これに答える ことができない. 本手法を利用することで, この問題解決への 道が開けると考える. 今後は, 業務データ相当の複雑さを持っ た形状データへ本手法を適用してその有効性を実証し, STEP におけるパラメトリック標準化への提案も検討してゆきたい.

\section{5. 結言}

本報では，フィレット面など複雑な形状処理を含む履歷再生 パラメトリック処理を複数のシステム間で共有する手法を提案 した. 特に, CAD のオペレーションを独立コンポーネントに分 割することにより複数のシステムで共有可能となることを主張 した.

\section{参 考 文 献}

1) R. Anderl and R. Mendgen : Parametric Design and its Impact on Solid Modeling Applications, ACM Proc. 3rd Symp. Solid Modeling, (1995) 1.

2) C.M.Hoffmann : On the Semantics of Generative Geometry Representation, Proc. ASME Design Automation Conf., (1993) 411.

3) V.Shapiro and D.Vossler : What is a Parametric Family of Solids?, ACM Proc. 3rd Symp. Solid Modeling, (1995) 43.

4) J.Kripac : A Mechanism for Persistently Naming Topological Entities in the History-Based Parametric Solid Modeling (Topological ID System), ACM Proc. 3rd Symp. Solid Modeling, (1995) 21.

5) J.Hoschek : Fundamentals of Computer Aided Geometric Design, A K Peters, Massachusetts,(1993).

6) R.E.Barnhill and S.N.Kersey: A Marching Method for Parametric Surface/Surface Intersection, Computer Aided Geometric Design 7, (1990) 257.

7) T.J.Peters, N.F.Stewart, D.R.Ferguson and P.S. Fussell : Algorithmic Tolerances and Semantics in Data Exchange, Proc. 19th Annual Symp. Computational Geometry, (1997) 403.

8) D.Agbodan, D.Marcheix and G.Pierra: A Data Model Architecture for Parametrics, J. for Geometry and Graphics, 3, 1, (1999) 17.

9) http://www.tc 184-sc4.org/

10）杉原厚吉, 伊理正夫 : 形状誤差による暴走の心配の無いツリッドモデ 亏の提案, 情報処理学会論文誌, 28, 9, (1987) 962 .

11) G. Heineman: Component Based Software Engineering, Addison Wesley, (2001)

12) N.Matsuki : A National R\&D Project Plan to Establish Manufacturing Information Infrastructure in Japan, Proc. ITIT Symp. Develop. Manuf. Technol. Infra., AIST, (2001) 6. 